Квасній Любов Григорівна кандидат економічних наук, доцент, професор МКА, Дрогобицький державний педагогічний університет імені Івана Франка, Прикарпатський інститут ім. М.Грушевського, вул. Івана Франка, 24, м. Дрогобич, 82100, тел.: (032) 239-92-63, e-mail: lg_k@ukr.net, https://orcid.org/ 0000-0001-5248-544X

Грицко Роман Юліанович кандидат медичних наук доктор наук 3 державного управління доцент кафедри інфекційних хвороб, Львівський Національний медичний університет ім. Д. Галицького, вул. Пекарська, 69, Львів, 79010, тел. (067) 701-05-56, e-mail: grytskoroman@gmail.com, https://orcid.org/ 0000-0001-7086-8399

Мураль Володимир Ярославович доктор філософії в галузі економіки, професор МКА, КЗ Львівської обласної ради «Самбірський фаховий медичний коледж», вул. Шевченка, будинок 14, м.Самбір, 81400, тел.: (096) 742-37-21, e-mail: v.mural@i.ua, https://orcid.org/0000-0002-3613-580X

\title{
РОЛЬ ІННОВАЦІЙНИХ МЕДИЧНИХ ТЕХНОЛОГІЙ В ПЕРІОД ПАНДЕМІї COVID-19
}

Анотація. У статті досліджено пандемію коронавірусу, яка стала каталізатором технологічних змін не тільки у всіх галузях промисловості, а й системі охорони здоров'я. За результатами дослідження виявлено, що традиційних методів недостатньо, щоб зупинити поширення вірусу 3 несподіваною швидкістю. Доведено, що в умовах карантину, спричиненого пандемією COVID-19, сталися глибинні перетворення корпоративної культури, комунікацій і наукових підходів до управління у системі охорони здоров'я на основі японської концепції створення суспільства 5.0, яка інноваційну технологію розглядає як інструмент вирішення стратегічних проблем та викликів держави на основі нових цифрових засад та нових медичних технологій таких як томографія, магнітний резонанс або швидкі методи виявлення раку та швидкі методи виявлення корона вірусної інфекції. Наявність цифрових технологій дозволило пом'якшити негативні наслідки пандемії як у соціальному, так і в економічному контексті, забезпечивши продовження функціонування територій та функцій, важливих для суспільства. Проаналізовано штучний інтелект який став ключовим чинником у винаході вакцини проти COVID-19, в якій бере участь весь науковий світ. Охарактеризована вакцинація як найбезпечніший спосіб набути імунітету проти COVID-19. Встановлено, що наразі розробляються вакцини проти мРНК SARS-CoV-2. Дослідження технології проводяться близько 20 років, і вона має великий потенціал для розробки вакцин, а також для лікування, наприклад, раку. 
У цьому контексті доведено, що вакцини з мРНК вважаються дуже безпечними через: відсутність можливості модифікувати ДНК пацієнта, відсутність можливості зараження, швидке розкладання мРНК 3 вакцини на нешкідливі компоненти та їх схожість з мРНК, що природно зустрічаються в клітинах, i дуже мала доза необхідна для досягнення терапевтичного ефекту. Охарактеризовано особливості телемедицини яка дозволила мінімізувати ризик подальшого поширення вірусу. Коли пандемія закінчиться, це може бути ефективним вирішенням проблеми подовження черг у клініках. Швидкі технологічні зміни також призводять до глибокого втручання в соціальну структуру. Втрата робочих місць або скорочення цілих секторів економіки, а також міграція суспільних відносин до мережі $є$ серйозними соціальними та економічними викликами. У цьому контексті доведено, що нові технології можуть вплинути не тільки на послуги охорони здоров'я, а й на ціни на житло або змінити співвідношення сил на ринку праці, що, безумовно, вимагатиме відповідних кроків, у тому числі відповідних нормативних актів у технологічному та медичному секторах. Ця ситуація вимагає планів, бачення та активних дій. Тому ми очікуємо зрілості, знань та відданості особам, які приймають рішення.

Ключові слова: пандемія COVID-19, суспільство 5,0, управління здоров'ям, вакцинація проти COVID-19, технологї̈ вакцинації мРНК.

Kvasniy Lyubov Hryhorivna Candidate in Economics Ph.D., Associate Professor, Professor of ICA, Drohobych State Pedagogical University named after Ivan Franko, Precarpathian Institute. M. Hrushevskoho, Ivana Franka St., 24, Drohobych, 82100, tel.: (032) 239-92-63, e-mail: lg_k@ukr.net, https://orcid.org/0000-0001-5248$544 X$

Hrytsko Roman Yulianovych Candidate of Medical Doctor of Science in Public Administration, Associate Professor of Infectious Diseases, Lviv National Medical University. D. Halytskoho, 69 Pekarska St., Lviv, 79010, tel.: (067) 701-05-56, e-mail: grytskoroman@gmail.com, https://orcid.org/0000-0001-7086-8399

Mural Volodymyr Yaroslavovych Doctor of Philosophy in Economics, Professor of ICA, KZ of Lviv Regional Council "Sambir Professional Medical College"; Shevchenko St., building 14, Sambir, 81400, tel.: (096) 742-37-21 e-mail: v.mural@i.ua, https://orcid.org/0000-0002-3613-580X

\section{THE ROLE OF INNOVATIVE MEDICAL TECHNOLOGIES DURING THE COVID-19 PANDEMIC}

Abstract. The article examines the coronavirus pandemic, which has become a catalyst for technological change not only in all industries, but also in the health care system. Research has shown that traditional methods are not enough to stop the virus from spreading at an unexpected rate. It is proved that in the conditions of quarantine caused by the COVID-19 pandemic, profound transformations of corporate culture, 
communications and scientific approaches to management in the health care system took place based on the Japanese concept of society 5.0, which considers innovative technologies as a tool for solving strategic problems and tasks. . states based on new digital principles and new medical technologies, such as tomography, magnetic resonance imaging or rapid methods of detecting cancer and rapid methods of detecting coronavirus infection. The availability of digital technologies has mitigated the negative effects of the pandemic in both the social and economic contexts, ensuring the continued functioning of territories and functions important to society. Artificial intelligence, which has become a key factor in the invention of the vaccine against COVID-19, in which the whole scientific world participates, is analyzed. Vaccination has been described as the safest way to gain immunity against COVID-19. SARS-CoV2 mRNA vaccines have been identified. This technology has been studied for about 20 years and has great potential for the development of vaccines, as well as for the treatment of, for example, cancer.In this context, it has been shown that mRNA vaccines are considered very safe due to: lack of ability to modify the patient's DNA, lack of infection, rapid decomposition of mRNA from the vaccine into harmless components and their similarity to mRNA that occurs naturally in cells. achieving a therapeutic effect. Features of telemedicine are described, which allowed to minimize the risk of further spread of the virus. When the pandemic is over, it can be an effective solution to the problem of queuing in clinics. Rapid technological change also leads to profound interference in the social structure. The loss of jobs or the reduction of entire sectors of the economy, as well as the migration of social relations to the network are serious social and economic challenges. In this context, it has been proven that new technologies can affect not only health services but also housing prices or change the balance of power in the labor market, which will certainly require appropriate steps, including relevant regulations in the technology and medical sectors. This situation requires plans, visions and actions. Therefore, we expect maturity, knowledge and dedication from decision makers.

Keywords: COVID-19 pandemic, society 5.0, health management, vaccination against COVID-19, mRNA vaccination technologies

Постановка проблеми. Пандемія COVID-19 прискорила процес цифрової трансформації, яка 3 роками поступово змінювала функціонування суспільств. Події останніх років показали, що нові технології у сфері охорони здоров'я виступають запорукою ефективних антикризових інструментів. Помічається важливість ефективності Інтернету, що дозволило перенести у віртуальний простір роботи, освіти та охорони здоров'я. Масово використовуються безконтактні платежі, цифрові покупки та телемедицина. За визначенням Всесвітньої організації охорони здоров'я (ВООЗ), телемедицина це метод надання послуг з медичного обслуговування там, де відстань $\epsilon$ критичним чинником. У цьому зв'язку актуальним постає питання: як скоро може виникнути нове суспільство 5,0, створене за японською концепцією суспільства 5.0, яка інноваційну технологію розглядає як інструмент вирішення стратегічних проблем та викликів держави на основі нових цифрових засад, 
оскільки маємо справу з багатовимірною, глобальною, болючою та тривалою кризою підсиленою пандемією COVID-19. У цьому аспекті управління здоров'ям відбуватиметься за допомогою електронних носіїв, а стан здоров'я буде контролюватися в режимі реального часу, результати аналізу будуть використані для профілактичної медицини та терапії.

Аналіз останніх досліджень і публікацій. Найбільш проривні інновації створюються під час найбільших глобальних криз: війн, крахів світових ринків, пандемій. У 2020 році COVID-19 змінив спосіб життя, процеси купівлі-продажу та процеси роботи. Проблеми, спричинені пандемією коронавірусу, вивчались i продовжують вивчатися науковцями 3 різних країн світу: Н. Парді, М.Хоган, Ф.Порте, Д.Вейсман, Ж.Маруггі,К.Жанг, Н.Жаскон та іншими. Книга під назвою "Щеплення від COVID-19. Інноваційні технології та ефективність " [1] являє собою збірник знань про щеплення, їх технології та їх легітимність у боротьбі 3 пандемією. Зміст у книзі підтримує медичну спільноту та медичні служби, які мають щоденні контакти з пацієнтами і зазвичай є першим джерелом знань для них. Це також джерело знань для 3МI та широкої громадськості, усіх, кому потрібні науково обгрунтовані знання про вакцинацію проти COVID-19, види вакцин та їх ефективність.

Дослідження науковців [1-4 ] показують, що інноваційні технології та винаходи в медицині оцінюються 3 точки зору ключових факторів, включаючи оригінальність, креативність, ефективність, амбіції пацієнтів та цінність, яку вони приносять суспільству. У рейтингу представлені як вже функціонуючі технології, так і прототипи з 24 категорій, включаючи сталий розвиток, добробут населення, екологію та здоров'я.

Дослідження за результатами глибинних інтерв'ю 3 власниками та топменеджерами українських компаній [5] показує, що 43 відсотки респондентів визнають, що вони більш продуктивні у віддаленій роботі. Однак після короткої ейфорії, спричиненої можливістю працювати вдома, також відчутними стали іï негативні наслідки: люди стали виснажені, і баланс між роботою та життям сильно похитнувся. Експерти 3 менеджменту 3 Університету Козьмінського показують, що, хоча продуктивність працівників зросла, їх здатність до творчого та інноваційного мислення падає. Основна причина полягає в тому, що контакти за допомогою відеоконференцій не здатні відобразити творчу атмосферу, яка виникає під час очних зустрічей. Так званий пандемічний мозок орієнтований на виживання, а це стає причиною того, що важко абстрактно мислити i придумувати нові ідеї.

Мета статті - дослідити роль інноваційних медичних технологій в період пандемії COVID-19 та можливість створення суспільства 5,0.

Виклад основного матеріалу. COVID-19 виявив слабкі сторони системи охорони здоров’я. У лікарнях закінчуються місця, заплановане лікування скасовується, а пацієнти мають обмежений доступ до лікарів. Нас чекає довга $\mathrm{i}$ болісна боротьба, яку для світової економіки може бути важко виграти і навіть неможливо без розвитку нових технологій. Практика показує, що пандемія коронавірусу стала каталізатором технологічних змін не тільки у всіх галузях 
промисловості, а й системі охорони здоров’я. Це прискорило оцифрування медичних послуг та процесів, ознайомило нас із можливостями вирішення важливих i менш важливих питань в Інтернеті та 3 можливістю повністю віддаленої роботи. Глобальна пандемія COVID-19, спричинена поширенням вірусу SARS-CoV-2, змусила нас змінити стан повсякденного життя - від роботи чи навчання, до проведення вільного часу та сім’ї життя.

Цьогорічний рейтинг показує, що найбільш важливими $\epsilon$ технології, пов'язані 3 екологією та здоров'ям. Більш того, очевидно, що інновації, спричинені коронавірусом, з'явилися практично у всіх сферах нашого життя.

Завдяки телемедицині консультації найкращих лікарів, включаючи вузькопрофільних фахівців, стають доступними в найвіддаленіших населених пунктах і навіть за їх межами. Наприклад, можна отримати планову терапевтичну допомогу свого лікаря, знаходячись на пляжі чи у закордонному відрядженні. Головне, щоб в наявності був смартфон із відповідним додатком, а також підключення до інтернету. Для пацієнтів цифрова охорона здоров'я відкриває цілком нові можливості, а серед безперечних переваг:

- максимально оперативна медична допомога;

• онлайн консультації лікарів найвищої кваліфікації;

- проведення консиліумів з отриманням альтернативних думок;

- мінімізація ризиків інфікування;

- економія часу та грошей.

Дослідження показують, що найбільш перспективною та розвиваючою технологією, безперечно, є штучний інтелект, можливості якого практично необмежені. HealthTech та MedTech - одна з галузей технологій, які набули особливого значення під час пандемії. Використання штучного інтелекту в галузі медицини не тільки сприяє більш точній діагностиці, але і дозволяє створювати індивідуальні методи лікування. TrialJectory - це служба, яка аналізує тисячі клінічних випробувань за допомогою Штучного інтелекту. Технологія аналізує всі відповідні варіанти лікування та викладає зрозумілою мовою лише те, що підходить для стану конкретного пацієнта.

За кожною кризою стоїть вибір: трактувати пї як загрозу чи можливість? Сьогодні, завдяки появі вакцин та вакцинації, ми маємо шанс отримати контроль над SARS-CoV- 2 і поступове повернення до звичного способу життя, який був до пандемії. Однак позитивні наслідки значною мірою залежать від масовості вакцинації - досягнення належного рівня імунізації широкої громадськості - а отже, від здорового глузду, знань та рішень кожного з нас.

У історія розвитку медицини імунізація населення - це одне 3 найбільших досягнень, відкриття, яке врятувало життя мільйонам людей. Це сприяло викоріненню смертельних та інвалідизуючих захворювань. Цілісний підхід до медицини та охорони здоров'я у боротьбі з інфекційними захворюваннями ніколи не мало більш ефективної зброї.

Багато людей ставляться до цього дуже скептично, навіть пропагують негативний підхід до щеплень. Наукова спільнота усвідомлює, що лише подолання соціальних страхів та дій, заснованих на достовірних та перевірених 
знаннях, може допомогти змінити ставлення людей до вакцинації та, таким чином, сприяти високому охопленню вакцинацією в період пандемії.

У грудні 2019 року в китайському місті Ухань з’явились стрімко розповсюджені спалахи важкої, неуточненої вірусної пневмонії. Етіологічним чинником цих випадків став новий коронавірус, передача якого в людській популяції досі точно не визначена. Всесвітня організація охорони здоров'я назвала його SARS-CoV-2 (важкий гострий респіраторний синдром, коронавірус2) та хворобу, яку він викликає COVID-19 (коронавірусна хвороба-2019). Вже 11 березня 2020 року

BOO3 оголосила про пандемію COVID-19. Незабаром його епіцентр перемістився з Азії до Свропи та Північної Америки. Навесні та влітку 2020 року найбільша кількість випадків за межами США була зафіксована в Італії, Іспанії, Франції та Великобританії.

Коронавіруси - це велика родина РНК - вірусів, що включає види, які заражають людей і тварин. У 1960-х роках було виявлено, що певні види коронавірусів тварин також можуть заражати людей. У 2019 році інший коронавірус тварин (згодом названий SARS-CoV-2) вдалося передати і поширити серед людей, спричинивши перші спалахи захворювання Китайської хвороби COVID-19. 11 березня 2020 року BOO3 оголосила про пандемію, епіцентр якої швидко почав переміщатися 3 Азії до Північної Америки та Свропи, що стала небезпечною для життя, особливо серед людей груп високого ризику, і епідемія цієї хвороби, з такою високою часткою пацієнтів, які потребують госпіталізації, швидко поширюється в системі охорони здоров’я.

Згідно $з$ аналізом госпіталізованих пацієнтів, зареєстрованих у базі даних SARSTer, рівень смертності, пов'язаний з COVID-19, становив 6,2\%, а лише доросле населення - 7,3\%. Однак смертність явно зростає після 60 років, і кожен п’ятий чоловік старше 80 років, який потребує стаціонарного лікування, помирає.

Тому припинення поширення пандемії та пов'язані з нею смерті потребують прискорення розвитку імунітету шляхом масової вакцинації.

Під час пандемії було запропоновано багато ліків, головним чином на основі практики та клінічного досвіду, в яких немає сумнівів щодо ефективності та безпеки кисневої терапії та низькомолекулярного гепарину у пацієнтів, які потребують госпіталізації.

На жаль, поява COVID-19 не гарантує розвитку стійкого імунітету до цієї хвороби. Тож перед нами стоїть простий вибір: вакцинуватись від COVID-19 або брати участь у важко передбачуваній лотереї, пов'язаній із захворюванням та подальшим погіршенням здоров'я населення.

Однак масштаби пандемії COVID-19 та легкість пересування людей означають, що лише глобальні дії, включаючи масову вакцинацію, зупинять вірусну циркуляцію.

Вакцинація - найбезпечніший спосіб набути імунітету проти COVID-19. Наразі розробляються вакцини проти мРHК SARS-CoV-2. Дослідження цієї технології проводяться близько 20 років, і вона має великий потенціал для розробки вакцин, а також для лікування, наприклад, раку. Вакцини з мРНК 
вважаються дуже безпечними через: відсутність можливості модифікувати ДНК пацієнта, відсутність можливості зараження, швидке розкладання мРНК 3 вакцини на нешкідливі компоненти та їх схожість 3 мРНК, що природно зустрічаються в клітинах, i дуже мала доза необхідна для досягнення терапевтичного ефекту. Важливо, що високі титри нейтралізуючих антитіл до SARS-CoV-2 були отримані через 7 днів після другої вакцинації у 90\% пацієнтів.

Також варто відзначити, що вакцини проти COVID-19, як і інші вакцини на фармацевтичному ринку $\mathrm{CC}$, проходять ретельні клінічні дослідження та процедури авторизації. Після того, як вакцини проти COVID-19 будуть схвалені для використання на ринку, їх безпечність буде продовжувати ретельно контролюватися відповідно до нормативних стандартів. Крім того, безумовне схвалення, дійсне протягом одного року, означає, що Свропейському агентству 3 лікарських засобів незабаром доведеться переглянути дані про використання цих вакцин у клінічній практиці.

8 грудня 2020 року було прийнято Національну програму вакцинації 3 урахуванням наведених вище рекомендацій Європейської Комісії. Через масовий масштаб, виробничі процедури та розповсюдження вакцин, дія вакцинації $\epsilon$ поетапною. Встановлено порядок пріоритетних груп, згідно 3 яким триватиме вакцинація. Медичні працівники зможуть спочатку зробити щеплення, будучи одночасно прикладом i основним джерелом знань для пацієнтів. У цьому контексті дуже важливою є освіта пацієнтів - усвідомлення ними важливості імунізації, їх ролі у запобіганні COVID-19, а отже, у відновленні якості сімейного, соціального та економічного життя. ВООЗ вважає, що потрібно протестувати якомога більшу кількість вакцин, оскільки не можна передбачити заздалегідь, скільки з них виявляться перспективними [195]. Зараз на сайті ВООЗ $\epsilon$ інформація про більш як 150 можливих вакцин від COVID-19, 21 з них уже проходять клінічні випробування, 139 - доклінічні [7].

У масиві великої кількості інформації, часто суперечливої або недостовірної, ми сподіваємося, що усунуться хоча б деякі сумніви щодо глобальної пандемії COVID-19, особливо щодо технології вакцинації мРНК, який інтенсивно розробляється для цієї хвороби, і який на даний момент є єдиною значною зброєю, яку ми маємо у боротьбі з SARS-CoV-2

Якщо дивитися більш глобально - на інновації країн чи цілих націй - Свропа працює досить добре. Звіт про інновації, опублікований Європейською Комісією у червні 2020 року (European Innovation Scoreboard) [5] показує, що європейське табло інновацій неухильно зростає, i в короткостроковій перспективі ця тенденція збережеться - дослідження не вказує на те, що пандемія зупинить або прискорить їі зростання.

Вивчаючи досвід Японії по створенню суспільства 5,0, вважаємо, що однією з особливих проблем для Японії є старіння населення. Хоча старіння не означає, що воно стає проблемою, воно має певні труднощі на різних рівнях, хоча деякі 3 них можуть (і будуть) ставати меншою проблемою внаслідок розумних підходів, які використовуються інноваційними медичними технологіями, але формуються розумними людьми. Дорога до цього суперрозумного суспільства прокладається 
на основі впровадження інноваційних технологій і врахування важливої їх ролі у таких сферах як Інтернет речей, штучний інтелект, кібер-фізичні системи, VR/AR, Big Data (аналітика) тощо. Хоча старіння населення $є$ проблемою для більшості країн, Японія на сьогоднішній день $\epsilon$ країною 3 «найстарішим» населенням, 26,3 \% - молодше 65 років.

Таким чином, на перспективу у сфері охорони здоров'я ставиться акцент не лише боротьбу з більш хронічними захворюваннями, які виникають з віком, але й переважно на пошук інноваційних шляхів реорганізації системи охорони здоров’я залежно від реальності старіння населення, впровадження цифрової трансформації та переосмислення ролі медичної допомоги, включаючи інноваційні технології, частково обумовлені тим, що люди просто старіють. У цьому плані Європа знову випереджає Сполучені Штати, але їй ще належить наздогнати таких світових лідерів, як Південна Корея, Австралія та Японія. Якщо поставити цю мету в перспективу: очікується, що по всьому світу понад 20 відсотків населення буде молодше 60 років до... .2050. По суті, це означає, окрім дивовижних цифр сьогодні в Японії, що всі країни повинні стежити за тим, що робить Японія, і як це суспільство 5.0 працює насправді. Тому в найближчі місяці та роки буде надзвичайно важливим скоординувати інноваційну політику СС для покращення його глобальної конкурентоспроможності. Інновації сьогодні відіграють ключову роль у подоланні пандемії коронавірусу. Зараз є значна потреба в так званих POC- (Point-Of-Care)-тестах, які не потребують складного лабораторного устаткування, і тому їх можна робити навіть вдома.

Висновки. Зміни, що відбулися у 2020-2021 роках, багато в чому переробили та переоцінили світ, який ми знали до цього часу. Тому вважаємо, що людство уже не повернеться до багатьох звичок, включаючи медицину. Фармацевтичні компанії змушені будуть стати підготовленими до змін, швидко адаптуватися до нових умов. Споживачі стануть більш обізнаними та стануть більш розсудливими у прийнятті рішень. Штучний інтелект стане розумнішим, і люди почнуть краще розуміти його переваги та небезпеки.

Пандемічний та непередбачуваний перебіг COVID-19, смертність понад 7\% у віковій групі 60-80 років і майже 20\% у групі старше 80 років, важко зрозумілий та складний патогенез інфекції, відсутність ефективних ліків та заперечення існування вірусу SARS-CoV-2 певними середовищами i надалі залишиться основою та метою усіх заходів, необхідних для стримування поширення інфекцій навіть в умовах створення суспільства 5.0..

У цьому зв'язку важливим та актуальним $є$ досягнення популяційного імунітету, гарантованого пацієнтами, за яких із невідомих, можливо генетично обумовлених причин ніколи не буде заражено пацієнтів, які заразилися COVID19, та пацієнтів, які були щеплені. Безперечно, найгірший метод досягнення імунітету населення - це дозволити інфекції вільно поширюватися. Це призводить до великих людських втрат і $є$ величезним тягарем для медичних послуг та економіки кожної країни. Також немає гарантії, що у всіх інфікованих виробиться імунітет, і немає впевненості в тому, як довго це триватиме. 


\section{Jimepamypa:}

1. Centers for Disease Control and Prevention. Understanding mRNA COVID-19 vaccines: URL: https://www.cdc.gov/coronavirus/2019-ncov/vaccines/different-vaccines/mrna.html

2. Pardi N., Hogan M.J., Porter F.W., Weissman D. (2018). mRNA Vaccines - a New Era in Vaccinology. Nature Reviews. Drug Discovery. 17(4): 261-279.

3. Maruggi G., Zhang C., Li J., Ulmer J.B., Yu D. (2019). mRNA as a Transformative Technology for Vaccine Development to Control Infectious Diseases. Molecular Therapy. 27(4) : 757-72.

4. Jackson N.C., Kester K.E., Casimiro D., Gurunathan S., DeRosa F. (2020). The Promise of mRNA Vaccines: A Biotech and Industrial Perspective. Npj Vaccines. 5(1):1-6.

5. Мірошниченко О.А.Наслідки епідемії COVID-19 та карантинних заходів для провідних секторів економіки України / О. А.Мірошниченко. Центр прикладних досліджень. К. : 2020. - 188 с.

6. European Innovation Scoreboard . Звіт про інновації. (2020). Брюссель, МА: European Innovation Scoreboard.

7. Draft landscape of COVID-19 candidate vaccines. WHO (2020). URL: https://www.who.int/who-documentsdetail/draft-landscape-of-covid-19-candidate-vaccines

\section{References:}

1. Centers for Disease Control and Prevention. Understanding mRNA COVID-19 vaccines: URL: https://www.cdc.gov/coronavirus/2019-ncov/vaccines/different-vaccines/mrna.html

2. Pardi N., Hogan M.J., Porter F.W., Weissman D.(2018). mRNA Vaccines - a New Era in Vaccinology. Nature Reviews. Drug Discovery. 17(4):261-279.

3. Maruggi G., Zhang C., Li J., Ulmer J.B., Yu D. (2019). mRNA as a Transformative Technology for Vaccine Development to Control Infectious Diseases. Molecular Therapy. 27(4) : 757-72.

4. Jackson N.C., Kester K.E., Casimiro D., Gurunathan S., DeRosa F. (2020). The Promise of mRNA Vaccines: A Biotech and Industrial Perspective. Npj Vaccines. 5 (1) :1-6.

5. Mirochnitchenko, O.A. (2020). Naslidky epidemii COVID-19 ta karantynnych zachodiv dlia providnych sektoriw ekonomiky Ukraini [Consequences of the COVID-19 epidemic and quarantine measures for the leading sectors of Ukraine's economy] Kyiv: Centr prikladnich doslidjen [in Ukrainian]

6. European Innovation Scoreboard . Zwit pro innowatsii. (2020). Brussel, MA: European Innovation Scoreboard.

7. Draft landscape of COVID-19 candidate vaccines. WHO. (2020). URL: https://www.who.int/who-documentsdetail/draft-landscape-of-covid-19-candidate-vaccines 